\title{
Information visualization in context of modern education megatrends
}

\author{
Nadezhda Izotova ${ }^{1}$, Marina Klimenko ${ }^{1}$, and Elena Nikolaenko, $^{1, *}$ \\ ${ }^{1}$ Bryansk State University, 14, Bezhitskya Str., 241036, Bryansk, Russia
}

\begin{abstract}
In light of technological advancement and formation of new visual culture, there arises a vital problem of visual presentation of information for solving new problems and performing a wider range of functions in education. In this regard, visualization should be considered in context of such megatrends as the Prosumer concept, knowledge management, the use of platform services to present information as a single unity. Cognitive visualization as the basis for visual presentation of educational information is represented by five main tendencies which students should take into consideration creating infographics: concentration and generalization of knowledge, expansion of the orientation and presentation functions of visual aids, algorithmization of educational and cognitive actions by visual means, and multicode presentation of information. Experimental training resulted in establishing connections between these megatrends and the cognitive visualization tendencies; besides it revealed that concentration of knowledge and multicode presentation of information were the most difficult information visualization operations for the students when using platform services for creating visual content.
\end{abstract}

\section{Introduction}

Technological progress and the formation of visual culture inevitably makes impact on the set of requirements for the modern education system. The information saturation of the modern educational space and its active digitalizationat present require rethinking all structural components of education process. In this case, modern megatrends are used as an undoubtful benchmark, which determine the vector of the development of teaching tools and methods, and also regulate the restructuring of all teaching aids in a new context, endowing them with new tasks and functions.

The need for more compact and effective teaching tools is becoming one of the most important tasks for society which needs to systematize and optimize the assimilation of knowledge (Kurilkina 2014). For further accumulation, assimilation, storage, processing and transmission of information there are required new, compact, mobile means of reflecting the objective world in the person's mind. Visualization is one of these tools.

Visualization of information plays an important role in educational process of any level; it is based on specific preparation of teaching aids and materials before presenting them to

\footnotetext{
* Corresponding author: vicpost@inbox.ru
} 
students. The interest in visualization is conditioned by the course of humankind development itself, the increasing flow of information to process which traditional means and methods are unsuitable and too complex. The visualization principle, or "the golden rule of didactics", has been known since the time of Jan Amos Komenský who declared that everything is arranged from above for harmony, so that everything which is higher can be represented by that which lower, that which is absent - by that which is present, the invisible - by the visible (Komenský 2000,p.300).Later the visualization principle in pedagogical science was developed in the works of Johann Heinrich Pestalozzi and Konstantin D. Ushinsky. In the Russian teaching methodology one of the vivid examples of the use of visualization is the use of "supportive"reference signals developed by Viktor F. Shatalov.

Visualization is understood as any way of ensuring observability of reality, and by the result of visualization or a visual model - any visually perceived structure that imitates the essence of the object of cognition (Izhdeneva 2015, p. 112). Visualization is treated as the transfer in the process of cognitive activity, from the inner plane to the outer plane, of mental images the form of which is spontaneously determined by the mechanism of associative projection (Schema Theory of R.S. Anderson and F. Bartlett, Frame Semantics of Charles J. Fillmore, M. Minsky, etc.). At the same time, visual information undergoes various transformations caused by psychological mechanisms of sensation, perception, representation, awareness and understanding.

The printed text as a source of information is built on the principles of disengaging the content from reality, it is characterized by such features as linearity, consistency, objectivity, rationality. These features form a way of thinking similar in its structure somewhat similar to some extent to the structure of a printed text (Akhmetova 2009, p. 4852). Meanwhile, visual images in photography, cinema, radio, television create structures that are significantly different from the structure of printed text. These visual structures create models of recognition, make focus on imagery, emotionality and irrationality. The psychological processes of sensation, perception, representation, awareness, understanding lie between the visual model and the visual object (Beresteneva, 17). Thus, visualization is a general name for the methods of presenting numerical information or a physical phenomenon in a form convenient for visual observation and analysis.

Recently considerable attention has been paid to cognitive visualization - a more complex phenomenon since it is not just the illustration of the subject under study but also its subsequent transformation and rethinking. Under cognitive-visual technology of presenting information, O.A. Kondratenko understands "a system of logically built and sequential actions aimed at visual transformation of educational material, the purpose of which is to increase the efficiency of work with educational information by activating cognitive processes" (Kondratenko 2013, p. 86). O.O.Knyazeva argues that cognitive-visual approach "allows to take into account individual characteristics of students and contributes to the development of their visual thinking" (Knyazeva 2003, p. 10). The essence and difference between cognitive visualization and the visualization principle is the shift of emphasis from the illustrative function in educating to the development of cognitive abilities and critical thinking. Thus, we can conclude that it is necessary to ensure suchconditions of learning which focus on using potentials of students' visual thinking.

We can also say that visualization is an intermediate link between educational material and learning outcomes. It is a kind of cognitive-evaluative mechanism that allows you "to condense" the process of cognition, to remove minor details from it and thus, improve and optimize it.The main functions of visualization in educational process are 1) ensuring synthesis of knowledge; 2) visual and indirect presentation of studied phenomenon in areas where visual perception is difficult or impossible; 3) increasing students' motivation to learn, since learning process itself becomes more diverse and interesting. From the didactic 
point of view, the use of visualization tools can perform general and specific functions in education (Makarova 2009, p. 13).

Among specific functions we can find motivating, clarifying, organizing, regulatory, operational, explaining, empirical, ideographic, interpreting and heuristic functions. To common functions belonginformativeness, integrity, instrumentality, adaptability andbeing compensatory in nature(Makarova 2009, p. 13).

At the same time, changes in higher education, the inevitable consequence of which are reforms in the field of the content of general scientific and professional training, the creation of new models of education process, significantly expand the functionality of visualization tools. New tasks and functions of these tools appear in the context of the implementation of the so-called megatrends in education which reflect the ongoing changes in the structure and approaches to the organization of education. We claim that they determine the vectors and direction of the further development of means of visual presentation of information.

Thus, the idea of visualization of educational information goes beyond the framework of its traditional interpretation functioning as a tool for the implementation of modern megatrends in education.

The overall aim of this research is to establish the relationship between visualization of educational information with modern trends in education by analyzing ways and methods of implementing strategies of cognitive visualization of information by students when designing infographics.

\section{Materials and methods}

To achieve the research goal - analyzing the relationship with modern megatrends in education -careful analysis of literature on research problems was carried out; ways and means of implementing these trends in the visual presentation of information in educational process were identified (on the basis of infographics). The theoretical methods which were applied, like analysis, synthesis, systemic research method, modeling, made it possible to identify a set of main trends that could potentially influence the use of visual means of presenting information. The analysis of research works on the problems of cognitive visualization made it possible to single out a set of basic trends in cognitive visualization involved in the creation of visualized educational content - infographic texts. To confirm the relationship and analyze it, we organized pilot training in which students were offered to independently create the means of visual presentation of information (infographics) using cognitive visualization techniques based on platform services. The participants of this experiment were 27 students of language educational program specialization of the first and second years of study (language proficiency level B2-B2 +) of Bryansk State University named after academician I.G. Petrovsky. The pilot training has three stages.

Preparatory stage. The teacher presents a problem for which visual content is to be developed, describes the specifics of this problem and clarifies the content, i.e., a set of content elements that should be reflected in the infographics they will create. The problem "HIGH-TECH HOUSES" was proposed as a thematic basis for the experiment. Further on, the participants were given a detailed instruction made by the teacher beforehand. The sample of the instruction is given in Table 1. 
Table 1. Instructions for designing infographics "HIGH-TECH HOUSES".

\begin{tabular}{|c|c|c|}
\hline Project & "HIGH-TECHHOUSES" & $\begin{array}{c}\text { Comments/ } \\
\text { Time }\end{array}$ \\
\hline TASK & Creating an infographic & \\
\hline STEP 1 & $\begin{array}{l}\text { Collect information on the topic } \\
\text { Make a hotlist on the topic }\end{array}$ & \\
\hline STEP 2 & $\begin{array}{l}\text { Choose } 2-3 \text { unusual houses (description/photo from } \\
\text { the outside and inside (if possible) }\end{array}$ & \\
\hline STEP 3 & $\begin{array}{l}\text { Specify the location of the houses (country, city, } \\
\text { region, district) } \\
\text { Name their creators/designers } \\
\text { Provide the description of their peculiarities (size, } \\
\text { shape, decoration, materials they are made of etc.) } \\
\text { Present statistics concerning their popularity } \\
\text { (number of visitors, ticket price etc.) }\end{array}$ & \\
\hline STEP 4 & $\begin{array}{l}\text { Use the site } \\
\text { (https://piktochart.com/ } \\
\text { /https://www.canva.com//https://wordwall.net/ } \\
\text { /https://www.renderforest.com/ } \\
\text { Choose the template, structurize the information you } \\
\text { have collected according to the template }\end{array}$ & \\
\hline STEP 5 & $\begin{array}{l}\text { Edit your infographic by adding images, statistics } \\
\text { and text }\end{array}$ & \\
\hline
\end{tabular}

Main stage. At the main stage the students developed infographics following the instructions and then presented the results on one of the selected platform services. A group of teachers ( 5 persons) made expert assessment of this created content following the criteria given in Table 2.

The given criteria reflect the requirements for visual content that can become educational, provided that each of the indicators is well achieved. The following assessment scale was used: 0 - does not correspond, 1 - weakly corresponds, 2 - generally corresponds, 3 - fully corresponds (the maximum value is 21 points). The suitability of infographics for use as educational content was considered possible under the conditions: 1) the absence of zero indicators, 2) if the average indicator is 12 points or more.

Table 2. Analysis of the final visual product.

\begin{tabular}{|l|l|}
\hline $\begin{array}{c}\text { Principle of } \\
\text { visual content } \\
\text { formation }\end{array}$ & \multicolumn{1}{|c|}{ Comments on the final product } \\
\hline Conformation & $\begin{array}{l}\text { Infographics is chosen as eye-catching visual content which contains a } \\
\text { minimum amount of text }\end{array}$ \\
\hline Authenticity & $\begin{array}{l}\text { Information provided is not distorted. All aspects of the problem are } \\
\text { considered }\end{array}$ \\
\hline Quality & $\begin{array}{l}\text { The image is of good quality, image resolution - 800x2000, with crisp, } \\
\text { sharp details, SVG format }\end{array}$ \\
\hline Completeness & There aresome extra clarifying data in form of color-scheme \\
\hline Consistency & The material is logically presented \\
\hline Simplicity & $\begin{array}{l}\text { Information is easy to perceive because of simple visual objects of the } \\
\text { infographics }\end{array}$ \\
\hline Optimality & $\begin{array}{l}\text { Information is given in a concise way. No overloading with a large } \\
\text { amount of information }\end{array}$ \\
\hline
\end{tabular}

Final stage. At this stage the participants were asked to evaluate their experience of creating infographics, considering also the implementation of cognitive visualization trends. The participants completed a Vizualization Questionnaire, which included questions about 
the process of creating-infographics experience. In accordance with the general purpose of the study, the following research question was formulated: To what extent was it difficult to develop strategies of creating infographics. The main questions are given in Table 3.

Table 3. Questionnaire on students' experience of designing infographics.

\begin{tabular}{|l|l|}
\hline \multicolumn{1}{|c|}{ Question } & \multicolumn{1}{|c|}{ Possible answers } \\
\hline $\begin{array}{l}\text { Did you like this form of working with } \\
\text { information? }\end{array}$ & Yes / No / Don't know \\
\hline $\begin{array}{l}\text { How difficult was it for you to search and select } \\
\text { the information for the Internet project? }\end{array}$ & 1 (easy)/2 (average difficult)/3(difficult) \\
\hline $\begin{array}{l}\text { How difficult was it for you to generalize } \\
\text { information andsingle out key characteristics of } \\
\text { objects under study from the data you found? }\end{array}$ & 1 (easy) / 2 (averagedifficult) / 3 (difficult) \\
\hline $\begin{array}{l}\text { How difficult was it for you to select a template } \\
\text { for presenting the data you found in the project? }\end{array}$ & 1 (easy) / 2 (averagedifficult) / 3 (difficult) \\
\hline $\begin{array}{l}\text { How difficult was it for you to present the material } \\
\text { in a structured way? }\end{array}$ & 1 (easy) / 2 (averagedifficult) / 3 (difficult) \\
\hline $\begin{array}{l}\text { How difficult was it for you to choose the form of } \\
\text { presenting your information (image, figure, } \\
\text { diagram, sign, etc.)? }\end{array}$ & 1 (easy) / 2 (averagedifficult) / 3 (difficult) \\
\hline $\begin{array}{l}\text { Working on the structure of the document / object, } \\
\text { you organized the information }\end{array}$ & $\begin{array}{l}\text { 1.according to the template } \\
\text { then transferred it to the template } \\
\text { 3. acted chaotically, without taking into } \\
\text { account the material that was collected }\end{array}$ \\
\hline
\end{tabular}

The results of the research made it possible to analyze the experience of using trends of cognitive visualization in the context of the implementation of megatrends in teaching foreign language in higher education institutions.

\section{Results}

\subsection{Modern trends of education in visualizing information}

The analysis of research works on the problems of the development of modern education let us single out a set of megatrends that affect such a component of educational process as information visualization. The main megatrends that influence the development and use of visual teaching aids, in our opinion, are the following:

1) the emergence of the concept of "prosumer" which implies that the modern student acts as a consumer and a producer all at once, hence it is necessary not only to use visualization tools in educational process so as to demonstrate education content but also to involve students in producing this education content by means of creating visualization tools by themselves,

2) knowledge management which includes gathering, structurizing, updating information, and by students themselves too, so as to continually replenish the information base with visual teaching aids thus contributing to its continued functioning,

3) the use of platform services as the basis for the integration of various services and educational products that make it possible to present information visually asonesingle unity.

Below is a detailed description of these megatrends. 


\subsection{1 'Prosumerism' in Education}

The term 'Prosumerism' was first coined by Alvin Toffler in his book 'The Third Wave' to denote people who produce some of the goods and services they then consume themselves - for example by making their own clothes, building their own cars, or cultivating vegetables for their kitchen (Toffler, 1980). Toffler envisaged a time when consumers would increasingly play a role as co-collaborators in production and supply chains, with the capacity to alter the design and the attributes of a product they wanted.

In the Higher Education sector, prosumerism has been associated with the shift towards 'learner-centred' teaching and learning activities, with the emphasis on student engagement and the co-production of knowledge. The argument is that greater student engagement in the teaching and learning process, and greater co-ownership of learning content, has a beneficial effect on learning outcomes (Bryson \& Han, 2007; Barklay, 2010). A typical approach applied across a spectrum of learning settings, including higher education, is the application of a 'blended learning' pedagogy, combining face to face teaching with a wide range of digital tools, with different tools being applied for different pedagogic purposes. For example, 'mind-mapping' tools aim to support students to link concepts and visualize them; simulations are applied to help students develop problem-solving and 'troubleshooting' skills; wikis are applied to support collaborative learning and student blogs to disseminate the content created by students in their assignments.

Thus, acquiring knowledge and skills to create their own content connected with information visualization is sure to enable students to solve many-fold tasks and carry out numerous assignments becoming creative, collaborative participants of the learning process. Content Creation - requires them to use digitaltechnologies to support learners to express themselves through digital means and to modify and create digital content in different formats (Caena\&Redecker, 2019).

In this respect, analysis of scientific studies and research results on visualization highlights and puts forward infographics as an educational tool of the greatest potential for the implementation of the megatrend consisting in the independent creation by the student of educational content with its subsequent use for organizing his own activities, improving various speaking skills and building interaction with other participants of educational process.

\subsubsection{Management of Knowledge}

Ourpresent-day knowledge society is based on increasing competition of individuals possessing not only knowledge but also constantly acquiring new knowledge and capableof creating this knowledge (Zhilina 2012, p. 186-187).

Today's society is fast-paced and it requires each individual to constantly master new knowledge which leads to increasing information load on every student and makes important not only the skills of searching for knowledge but also its updating and determining its priority. At the same time, knowledge creation skills such as skills in design, research and information analysis, are important asnever before (Zhilina 2012, p. 186-187). And hence the same important are the skills of presenting the results of information processing in form suitable for its subsequent assimilation and analysis. Among knowledge use skills we can find skills of solving problems, creating new products and disseminating knowledge. All the above mentioned skills should be defined as "knowledge management" skills, or, if to say more precisely, knowledge self-management skills (Zhilina 2012, p. 186-187). 
In this regard, an important skill is presentation of information under study in visual form with the purpose of its subsequent use as educational content not only by students who created it but also by all other students.

\subsubsection{Using platform services as the basis for the integration of various services and educational products that make it possible to present information visually as one single unity}

When we speak about students' independent creation of educational content the following problem comes to the fore: how to choose the most optimal service for creating various kinds of infographic texts, with a sufficient set of tools for editing and subsequent presentation.

In this situation, the role of the teacher is to introduce tostudents various services by providing them with links and a brief description of the options these services offer to create visual content within the framework of the problem under study.

\subsection{Cognitive visualization tendencies}

In this research we consider cognitive visualization as a technique of forming and improving knowledge management skills for each individual student. In the process of visualization, a person who makes knowledge "visible" mobilizes resources of figurative, logical and complex thinking, as well as aesthetic, cultural and artistic potential as well as other important personal qualities (Manko, 2009). The main goal of cognitive visualization is the development of methods and means of purposeful creation of mental images in the process of educational and cognitive activity and the presentation of these images in form accessible for perception. In this case, the product of cognitive visualization is a mental image formed by man's consciousness that determines the object (phenomenon) under study and is represented in the external plane of education process (Manko, 2009).

We argue that infographics as a graphical way of presenting information can be treated as a material product of cognitive visualization.

The process of creating a mental image as the basis of infographics is based on five tendenciesof cognitive visualization, each of which reflects the essence of the student's educational actions and is represented by certain visual knowledge representation technologies (Manko, 2009).

Following Natalia N. Manko's theory, we also consider these tendencies as a methodological basis for organizing students' activities of creating infographics.

1. Concentration of knowledge involves an increase of density and richness of information mastered by the student. This tendency manifests itself in the technologies of compression and consolidation of the material which students study to create infographics. This tendency is responsible for the formation of basic knowledge that ensures that a generalized and figuratively structured idea about the object under study is complete.

2. Generalization of knowledgeis the presentation of the essential conceptual semantic core of the concept under study, refined from details, trite descriptions, etc. This tendency is based on technologies that contribute to the optimization of methods for processing large amounts of information in a short time. In particular, it deals with meaning generalizations, i.e., highlighting the most general concepts associated with the object (phenomenon) under study.

3. Expansion of the orientation and presentation functions of visual aids (visual support tendency)is the location of important educational material in a logical sequence using "supportive" reference signals and keywords. 
4. Algorithmization of educational and cognitive actions by visual meansis a stageby-stage formation of knowledge general images by means of analyzing, singling out elements and their relationships.

5. Multicode presentation of information is the simultaneous use of different forms of naming information using various verbal, visual, multimedia, digital material codes, like an object, image, word, abbreviation, symbol, picture, drawing, graphics, pictogram, number, model.

\subsection{Description of the experience of creating infographics based on cognitive visualization tendencies}

Based on the results of trial training, the students created infographics in accordance with all the requirements. They created 27 infographic teaching aids on the problem"HIGHTECH HOUSES". The examples of students' works are shown in Figures 1.
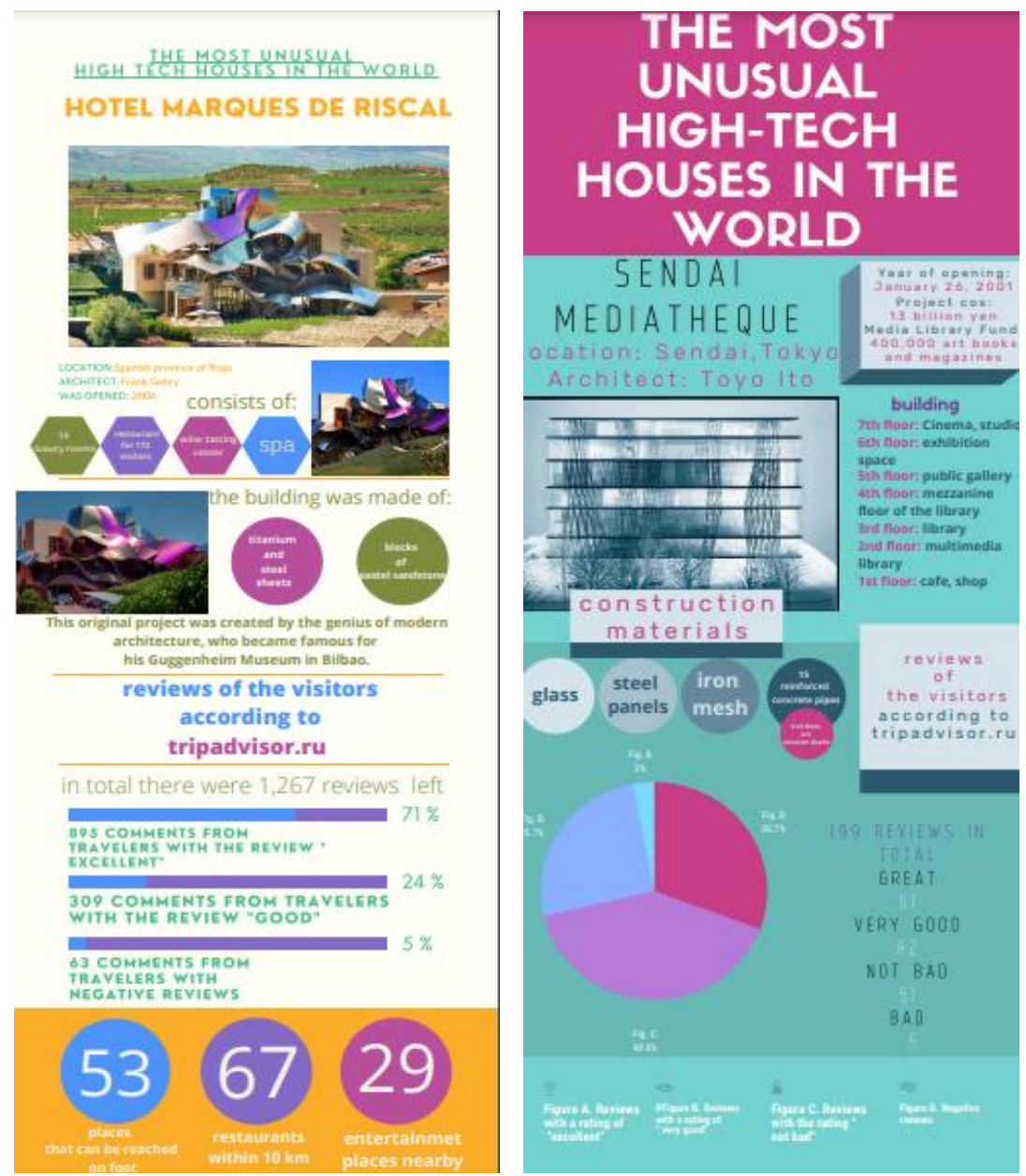

Fig. 1. The example of student's work.

The assessment of the created products showed that $14.8 \%$ (4 out of 27 ) of the works did not score the required number of points and thus do not satisfy the requirements to be used as educational content (they scored zero or their point total was no more than 11). At 
the same time the experts considered 23 works $(85.2 \%)$ satisfying the requirement to be included in education process as teaching materials in accordance with the selected criteria.

The questionnaire resultson the students' use of cognitive visualization tendencies as a basis for development of knowledge management skills when creating infographics are given in Table 4.

Table 4. Questionnaire results on students' experience of designing infographics.

\begin{tabular}{|l|c|c|c|}
\hline \multicolumn{1}{|c|}{ Question } & Yes & Don't know & No \\
\hline $\begin{array}{l}\text { Did you like this form of working with } \\
\text { information? }\end{array}$ & $\begin{array}{c}92.6 \% \\
(25)\end{array}$ & $\begin{array}{c}2.4 \% \\
(2)\end{array}$ & - \\
\hline easy & $\begin{array}{c}\text { average } \\
\text { difficult }\end{array}$ & difficult \\
\hline $\begin{array}{l}\text { How difficult was it for you to search and } \\
\text { select the information for the Internet } \\
\text { project? }\end{array}$ & $\begin{array}{c}22.2 \% \\
(6)\end{array}$ & $\begin{array}{c}63 \% \\
(17)\end{array}$ & $\begin{array}{c}14.8 \% \\
(4)\end{array}$ \\
\hline $\begin{array}{l}\text { How difficult was it for you to generalize } \\
\text { information andsingle out key } \\
\text { characteristics of objects under study } \\
\text { from the data you found? }\end{array}$ & $\begin{array}{c}55.6 \% \\
(15)\end{array}$ & $\begin{array}{c}33.3 \% \\
(9)\end{array}$ & $\begin{array}{c}11.1 \% \\
(3)\end{array}$ \\
\hline $\begin{array}{l}\text { How difficult was it for you to select a } \\
\text { template for presenting the data you } \\
\text { found in the project? }\end{array}$ & $\begin{array}{c}66.6 \% \\
(18)\end{array}$ & $\begin{array}{c}22.2 \% \\
(6)\end{array}$ & $\begin{array}{c}11.1 \% \\
(3)\end{array}$ \\
\hline $\begin{array}{l}\text { How difficult was it for you to present the } \\
\text { material in a structured way? }\end{array}$ & $\begin{array}{c}44.45 \% \\
(12)\end{array}$ & $\begin{array}{c}44.45 \% \\
\mathbf{( 1 2 )}\end{array}$ & $\begin{array}{c}11.1 \% \\
(3)\end{array}$ \\
\hline $\begin{array}{l}\text { How difficult was it for you to choose the } \\
\text { form of presenting your information } \\
\text { (image. figure. diagram. sign. etc.)? }\end{array}$ & $\begin{array}{c}37.05 \% \\
(10)\end{array}$ & $\begin{array}{c}44.45 \% \\
\mathbf{( 1 2})\end{array}$ & $\begin{array}{c}18.5 \% \\
(10)\end{array}$ \\
\hline
\end{tabular}

It is obvious that designing infographics provokes the interest of the majority of the students. Among the cognitive visualization tendencies which are reflected in the students' actions the most difficult was multicode naming of information (10 out of 27)since many students failed to select correctly a system of images to represent information or experienced difficulties in selecting one of these forms.

Less difficult it was to work with knowledge concentration, generalization and algorithmization realized by visual means - only1 $1,1 \%$ of the participants found it not easy. The easiest for the students wasvisual support tendencies since the participants relied mainly on ready-made templates of platform services they used - $66.6 \%$ (18 out of 27) built the logics of presenting structural links on the basis of a template.

\section{Discussion}

Infographics has the greatest potential for the implementation of the megatrend of independent creation of educational content with its subsequent use for organizing personal activities, improving various speaking skills and organizing interaction with other participants of education process.

In relation to language teaching, infographics is defined as a visual aid, a means of teaching, a way of teaching, a principle of teaching, etc. Anna E. Basyrova claims that infographics is such a kind of information presentation that can be both a means and a way of teaching at once.The researcher uses this term speaking about "a way of presenting information, information, data or knowledge using a combination of verbal and illustrative components, designed for fast and concise presentation of a problem under study, and also designed to improve the perception of information and to encourage the student to read it"; 
and also puts forward the term "infographic text" considering infographics to be a kind of creolized texts (Basyrova 2016, p.24).

Discussing the problem of infographics as one of the actively used visual types of content, Olga V. Khomenko speculates what characteristics objects should have to make information accessible for perceiving: information value, accessibility of presented material, relevance of the information and simple form of its presentation (Khomenko 2018,p.96). Studying samples of infographics, the researcher singled out several characteristics of high-quality visualization - integrity, simplicity, visual expression, information value, relevance and interestingness.

Elements of infographics have great potential when used for teaching vocabulary in foreign language classroom, expanding students' vocabulary and developing speaking and writing skills.

Thus, in foreign language classroom, infographics is aimed at solving the following tasks:

1) providing more information other than textbook,

2) explaining concept or presenting process,

3) drawing analogies and making comparisons,

4) being an intermediary in sharing data,

5)provingprovocative ideas for organizing and conducting discussions, debates, brain storming.

The independent creation of infographics by students as an element of the knowledge management system involves the use of all five tendencies ofinformation cognitive visualization and can be presented as a process that includes three stages: preparatory, main and final. The content of each stage and its correlation with cognitive visualization tendencies are presented in Table 5.

Table 5. Stages of students' creating infographics.

\begin{tabular}{|c|c|c|c|}
\hline Stage & Content & $\begin{array}{l}\text { Visualization } \\
\text { tendency }\end{array}$ & $\begin{array}{c}\text { Visual } \\
\text { presentation } \\
\text { technologies }\end{array}$ \\
\hline Preparatory & $\begin{array}{l}\text { - first acquaintance with the } \\
\text { concept/phenomenon } \\
\text { - search for information } \\
\text { - identification of basic } \\
\text { knowledge that most fully } \\
\text { characterizes the concept } \\
\text { /phenomenon }\end{array}$ & $\begin{array}{l}\text { Concentration } \\
\text { knowledge }\end{array}$ & $\begin{array}{l}\text { compression } \\
\text { consolidtion }\end{array}$ \\
\hline \multirow[t]{2}{*}{ Main } & $\begin{array}{l}\text { - singling out the most general } \\
\text { concepts associated with the } \\
\text { object/phenomenon under study } \\
\text { - choosing the logics of locating } \\
\text { studied phenomena, } \\
\text { characteristics and actions }\end{array}$ & $\begin{array}{l}\text { Generalization } \\
\text { knowledge }\end{array}$ & $\begin{array}{l}\text { meaning } \\
\text { generalization } \\
\text { images } \\
\text { logical } \\
\text { constructs }\end{array}$ \\
\hline & $\begin{array}{l}\text { - selecting factual material for its } \\
\text { presentation in infographics } \\
\text { - building visual support } \\
\text { - choosing a template for } \\
\text { infographics }\end{array}$ & $\begin{array}{l}\text { Expansion of the } \\
\text { orientation and } \\
\text { presentation functions } \\
\text { of visual aids (visual } \\
\text { support tendency) }\end{array}$ & $\begin{array}{l}\text { framestructuring } \\
\text { visual support }\end{array}$ \\
\hline Final & $\begin{array}{l}\text { - forming a general image of an } \\
\text { object/phenomenon based on } \\
\text { analysis, selection of elements } \\
\text { and their relations } \\
\text { - arranging the structural } \\
\text { elements of the template in }\end{array}$ & $\begin{array}{l}\text { Algorithmization of } \\
\text { educational and } \\
\text { cognitive actions by } \\
\text { visual means }\end{array}$ & $\begin{array}{l}\text { data } \\
\text { arrangement }\end{array}$ \\
\hline
\end{tabular}




\begin{tabular}{|l|l|l|l|}
\hline & $\begin{array}{l}\text { necessary sequence according to } \\
\text { the logics of the presentation of } \\
\text { the created mental image of the } \\
\text { object/phenomenon }\end{array}$ & & \\
\hline $\begin{array}{l}- \text { choosing forms of naming } \\
\text { information for each structural } \\
\text { element of the mental image }\end{array}$ & $\begin{array}{l}\text { multicode } \\
\text { presentation } \\
\text { information }\end{array}$ & $\begin{array}{l}\text { sign and } \\
\text { semantic coding }\end{array}$ \\
\hline
\end{tabular}

Creating infographics involves the use of appropriate platform services. As part of the given research, we have studied and analyzed several online infographics creating services of various kinds as a type of visual content. The brief information about them is given in Table 6.

Table 6. Overview of infographicscreation services.

\begin{tabular}{|c|c|c|}
\hline Name of service & Brief description & Link \\
\hline Pictochart & $\begin{array}{l}\text { Online editor } \\
\text { Offers the user great opportunities for } \\
\text { developing and presenting information in } \\
\text { infographic format. } \\
\text { The user can choose a necessary template } \\
\text { from } 400 \text { professionally designed } \\
\text { templates of infographics, posters, reports } \\
\text { and presentations in the library editor, or } \\
\text { can start his project. } \\
\text { Has a library of } 4,000 \text { icons and images, } \\
\text { editable frames whichallow to } \\
\text { combineeasily a text with visuals and } \\
\text { photographs. }\end{array}$ & https://piktochart.com/ \\
\hline Canva & $\begin{array}{l}\text { Freegraphics editor. } \\
\text { Good for design novices as well as } \\
\text { professionals. Allows you to quickly and } \\
\text { easily make creative videos, presentations } \\
\text { and other visuals. }\end{array}$ & $\underline{\text { https://www.canva.com/ }}$ \\
\hline Wordwall & $\begin{array}{l}\text { Can be used to create both interactive and } \\
\text { printed materials. Many templates are } \\
\text { available in both online and print } \\
\text { versions. } \\
\text { Can be used on different gadgets - a } \\
\text { computer, tablet, phone, or whiteboard. } \\
\text { Can be shown by students themselves, or } \\
\text { by students under the supervision of a } \\
\text { teacher. } \\
\text { Printed materials can be printed out or } \\
\text { downloaded as a PDF file. They can be } \\
\text { used as additional material for interactive } \\
\text { means or as independent assignments. }\end{array}$ & https://wordwall.net/ \\
\hline Renderforest & $\begin{array}{l}\text { The platform for free creation of videos, } \\
\text { animation videos, product or service } \\
\text { commercials, kinetic typography projects, } \\
\text { animation logos, etc. } \\
\text { Offers ready-made templates which } \\
\text { greatly simplifies your work, but at the } \\
\text { same time does not deprive it of } \\
\text { uniqueness. } \\
\text { Has about } 400 \text { templates for commercials, } \\
\text { slideshows, presentations and animated }\end{array}$ & https://www.renderforest.com/ \\
\hline
\end{tabular}




\begin{tabular}{|c|c|c|}
\hline & & $\begin{array}{l}\text { logos. } \\
\text { Has a large library - about } 200,000 \text { stock } \\
\text { videos, dozens of unique commercial } \\
\text { soundtracks. A simple online video editor } \\
\text { and voice-over tool. Import of your } \\
\text { pictures, audio and video. }\end{array}$ \\
\hline
\end{tabular}

Thus, the creation of infographics involves the students' developing knowledge management skills based on gathering, structuring and arrangement of information while creating a visual product. This process involves the use of the main tendenciesof visual representation of knowledge: generalization and concentration of knowledge, creation of a logical and semantic support, knowledge algorithmization and informationmulticode presentation.

\section{Conclusion}

Visual presentation of information is an integral part of education process. It is the correctly selected visual content which determines the level of perception, memorization and subsequent reproduction of information within the framework of material under study.

In the situation when a student performs both as a consumer and a creator of educational content, managing at the same time the created visual information resource, improving and transforming it in accordance with changing goals, objectives and conditions based on the use of various platform services, the use of infographics as an educational tool allows systematically and in a stage-by-stage way to implement the main megatrends in education.

Infographics as one of the methods of cognitive visualization makes it possible, first, to independently create visual content using a system of precisely formulated sequential educational actions - of concentrating and generalizing knowledge, structuring educational material, algorithmisizing educational and cognitive actions and multicode presentation of information (as a simultaneous use of different forms of information presentation).

Secondly, because of the necessity to use various tools when creating this content, it is required to search for platform services thus resulting instudents' working with a variety of services to create different kinds of infographic materials. this also implements the megatrend of the integration of various services and educational productsallowing you to present information visually as a single unity.

\section{References}

1. L.V. Akhmetova, Vestnik TSPU 7, 48-52 (2009)

2. A.E. Basyrova, Materials of the IV International Scientific and Methodological conference (Voronezh, Nauchnayakniga, 2016)

3. O.G. Beresteneva, Cognitive graphics in social and psychological research (2013) http://cyberleninka.ru/article/n/kognitivnaya-grafika-v-sotsialno-psihologicheskihissledovaniyah

4. C. Bryson, L. Hand, Innovations in Education and Teaching International 44(4), 349362 (2007) http://dx.doi.org/10.1080/14703290701602748

5. F. Caena, C. Redecker, European Journal of Education, Research and Policy 54, 356369 (2019)

6. A.I. Zhilina, Regional education of XXI century: problems and perspectives 4, 184-192 (2012)

7. I.V. Izhdeneva, Vestnik KSPU named after V.P. Astafiev 1(31), 53-157 (2015) 
8. O.O. Knyazeva, Implementation of the cognitive-visual approach in teaching high school students the basics of mathematical analysis: dissertation, PhD in pedagogic sciences (Omsk, 2003)

9. J.A. Komenský, Selected pedagogical writings (Moscow, 2000)

10. O.O. Kondratenko, Theory and practice of social development 6, 84-88 (2013)

11. V.N. Kurilkina, Vestnik of M.K. Ammosov North-Eastern Federal University 1, 73-77 (2014)

12. E.A. Makarova, Visualization as a way of structuring knowledge and forming mental space (Taganrog, Taganrog Institute of Management and Economics, 2009)

13. N.N. Manko, Izvestia of Ural Branch of the Russian Academy of Sciences 8(65), 10-30 (2009)

14. O.V. Khomenko, Educational technologies and society 1, 264-270 (2018)

15. A. Toffler, The third wave: The classic study of tomorrow (New York, NY, Bantam, Google Scholar, 1980) 